\title{
NRAS NP_002515.1:p.Q61R
}

National Cancer Institute

\section{Source}

National Cancer Institute. NRAS NP 002515.1:p.Q61R. NCI Thesaurus. Code C98456.

A change in the amino acid residue at position 61 in the GT Pase NRas protein where glutamine has been replaced by arginine. 